\title{
Скорость и качество решений лингвистических заданий с эмоциональными предложениями как возможный поведенческий маркер, отражающий адаптацию человека к приполярному климату
}

\author{
Белоногов А. ${ }^{1 *}$, Выскребцов А. ${ }^{1}$, Таможников С. ${ }^{2}$, Борисова Н. ${ }^{3}$, Афанасьева Е. ${ }^{3}$, Никонов H. $^{4}$, \\ Чикачева C. ${ }^{4}$, Савостьянов A. ${ }^{1,2,5}$ \\ ${ }^{1}$ Новосибирский государственный университет, ЛБМСПЧ ГИ, Новосибирск, Россия \\ ${ }^{2}$ НИИ физиологии и фундаментальной медицины, Новосибирск, Россия \\ ${ }^{3}$ Северо-Восточный Федеральный Университет им. М.К. Аммосова, Якутск, Россия \\ 4 Якутский Медииинский колледж, пос. Хандыга, Республика Саха, Россия \\ ${ }^{5}$ Институт циитологии и генетики СО РАН, Новосибирск, Россия \\ *e-mail: a.belonogov@g.nsu.ru
}

Ключевые слова: климатическая адаптация, моторный контроль, ERP, стоп-сигнал парадигма

Мотивация и цеель: Адаптация к условиям экстремального климата сопровождается повышенным риском развития аффективной патологии, включая тревожное расстройство и депрессию. Одной из когнитивных способностей, имеющих критически важное значение для успешности адаптации, является возможность распознавать эмоциональное состояние других людей. Целью данного исследования было изучение поведенческих показателей в условиях распознавания эмоциональной речи, отражающих состояние мигрантов при долговременной адаптации.

Meтоды и алгоритмы: В обследовании приняло участие 50 молодых, здоровых жителей поселка Хандыга (арктический район Якутии) и 50 здоровых мигрантов, приехавших в Якутию на длительный срок из южных регионов (Средняя Азия, Африка). Мигранты обследованы дважды сразу же после приезда в Якутию и через полгода после переезда. В эксперименте испытуемые выполняли задания по распознаванию грамматической структуры письменных предложений, выражавших разные эмоциональные состояния человека. Экспериментальные результаты сопоставлялись с поведенческими опросниками, которые тестировали риск развития аффективной патологии и личностные особенности людей.

Результаты: Выявлено, что низкий риск развития депрессии у мигрантов связан с высоким уровнем показателей индивидуализма и низкой привязанностью к оставленной дома семье. В поведенческом эксперименте повышенный уровень стресса при адаптации вызывал снижение скорости и качества решения экспериментальных заданий с предложениями, описывающими ситуации агрессии.

Заключение: Анализ поведенческих реакций в условиях распознавания эмоциональной речи позволяет оценить общий уровень стресса и предрасположенность к аффективным нарушениям у людей, в момент адаптации к новым условиям жизни.

Благодарности: Поддержано грантом РФФИ № 18-415-140021 и № 18-29-13027. Исследование А.Н. Савостьянова проводятся в рамках бюджетного проекта ИЦиГ СО РАН № 0324-2019-0040-С-01. 